\title{
PENGARUH PENERAPAN GOOD CORPORATE GOVERNANCE TERHADAP KINERJA PERUSAHAAN PADA PERUSAHAAN PERBANKAN YANG TERDAFTAR DI BEI
}

\author{
Maria Stefania Waro Bheri ${ }^{\mathrm{a}}$,Suwignyo Widagdo ${ }^{\mathrm{b}}$, Lia Rachmawati $^{\mathrm{c}}$ \\ aMahasiswa STIE Mandala, fani5waro@gmail.com \\ ${ }^{b}$ Dosen STIE Mandala, suwignyo@stie-mandala.ac.id \\ ${ }^{c}$ Dosen STIE Mandala, lia_rachmawati@stie-mandala.ac.id
}

\section{N F O A R T I K E L}

Riwayat Artikel:

1 Oktober 2021

31 Oktober 2021

9 November 2021

\section{Keywords:}

Independent Board of

Commissioners, Board of

Directors, Audit Committee,

Company Performance.

\section{Kata Kunci:}

Dewan Komisaris Independen, Dewan Direksi, Komite Audit, Kinerja Perusahaan

\begin{abstract}
A B S T R A C T
This study aims to determine the effect of Good Corporate Governance consisting of the number of independent commissioners, the number of the board of directors, the number of audit committees on the company's performance in banking companies listed on the IDX. The population in this study are banking companies listed on the Indonesia Stock Exchange as many as 46 banking companies in Indonesia that are listed or go public. The sample in this study were 10 banking companies with four years of financial statements from 2017 - 2020 listed on the IDX. The sampling technique used is purposive sampling. Data collection uses secondary data taken from www.idx.co.id. The analysis technique used is multiple linear regression analysis. The results of the research data show that Good Corporate Governance which consists of the number of independent commissioners, the number of the board of directors, the number of audit committees together has a positive and significant effect on company performance in banking companies. The results of the significance test partially state that the number of independent commissioners has a negative effect, the number of boards of directors has a positive effect, while the number of audit committees has no effect on company performance.
\end{abstract}

\section{A B S T R A K}

Penelitian ini bertujuan untuk mengetahui pengaruh Good Corporate Governance yang terdiri dari jumlah dewan komisaris independen, jumlah dewan direksi, jumlah komite audit terhadap kinerja perusahaan pada perusahaan perbankan yang terdaftar di BEI. Populasi dalam penelitian ini adalah perusahaan perbankan yang terdaftar di BEI sebanyak 46 perusahaan perbankan di Indonesia yang listing atau Go Public. Sampel dalam penelitian ini adalah 10 perusahaan perbankan 
dengan empat tahun laporan keuangan mulai 2017 - 2020 yang terdaftar di BEI. Teknik pengambilan sampel yang digunakan adalah purposive sampling. Pengumpulan data menggunakan data sekunder yang diambil dalam www.idx.co.id. Teknik analisis yang digunakan adalah analisis regresi linear berganda. Hasil penelitian data menunjukkan bahwa Good Corporate Governance yang terdiri dari jumlah dewan komisaris independen, jumlah dewan direksi, jumlah komite audit secara bersama sama berpengaruh positif dan signifikan terhadap kinerja perusahaan pada perusahaan perbankan. Hasil uji signifikasi secara parsial menyatakan bahwa jumlah dewan komisaris independen berpengaruh ke arah negatif, jumlah dewan direksi berpengaruh positif sedangkan jumlah komite audit tidak berpengaruh terhadap kinerja perusahaan.

\section{PENDAHULUAN}

Salah satu tujuan penting pendirian suatu perusahaan adalah untuk meningkatkan kesejahteraan pemiliknya atau pemegang saham, atau memaksimalkan kekayaan pemegang saham melalui peningkatan kinerja perusahaan. Peningkatan kinerja perusahaan tersebut dapat dicapai jika perusahaan mampu beroperasi dengan mencapai laba yang ditargetkan. Melalui laba yang diperoleh tersebut perusahaan akan mampu memberikan dividen kepada pemegang saham, meningkatkan pertumbuhan perusahaan dan mempertahankan kelangsungan hidupnya. Globalisasi memunculkan adanya persaingan ketat antar perusahaan. Perusahaan saling berlomba untuk memaksimalkan kinerja perusahaannya, karena kinerja perusahaan yang baik akan menarik investor untuk menanamkan modal di perusahaan tersebut. Adanya tambahan modal dari investor akan menciptakan prospek yang lebih besar bagi masa depan perusahaan.

Kinerja Perusahaan merupakan suatu gambaran tentang kondisi keuangan suatu perusahaan yang dianalisis dengan menggunakan alat alat analisis keuangan sehingga dapat diketahui baik atau buruk keadaan keuangan suatu perusahaan dalam periode jangka waktu yang sudah ditentukan. kinerja perusahaan adalah hasil dari serangkaian proses bisnis yang mana dengan pengorbanan berbagai macam sumber daya, apabila kinerja perusahaan meningkat, bisa dilihat dari gencarnya kegiatan perusahaan dalam rangka untuk menghasilkan keuntungan yang sebesar-besarnya. Ukuran perusahaan menurut Indarti (2013) merupakan nilai yang menunjukkan besar kecilnya perusahaan. Kinerja perusahaan bisa juga diukur dengan menggunakan informasi keuangan atau juga menggunakan informasi non keuangan. Informasi non keuangan ini dapat berupa kepuasan pelanggan atas pelayanan yang diberikan oleh perusahaan. Meskipun begitu, kebanyakan kinerja perusahaan diukur dengan rasio keuangan dalam periode tertentu (Chariri dan Gonzali).

Dalam sebuah perusahaan manajer sebagai pengelola perusahaan mempunyai tujuan yang berbeda terutama dalam hal peningkatan prestasi individu dan kompensasi yang akan diterima. Jika manajer perusahaan melakukan tindakan-tindakan yang mementingkan diri sendiri dengan mengabaikan kepentingan investor maka akan menyebabkan jatuhnya harapan para investor tentang pengembalian (return) atas investasi yang telah mereka tanamkan. Oleh karenanya dibutuhkan adanya suatu perlindungan 
terhadap berbagai pihak yang berkepentingan dengan perusahaan tersebut (Almilia dan Sifa, 2006).

Salah satu upaya untuk meningkatkan kinerja perusahaan, dan sebagai serangkaian mekanisme untuk mengarahkan dan mengendalikan suatu perusahaan agar operasional perusahaan berjalan sesuai dengan harapan para pemangku kepentingan (stakeholders) adalah dengan cara menerapkan good corporate governance.Good corporate governance diperlukan untuk menjaga kelangsungan hidup perusahaan melalui pengelolaan yang didasarkan pada asas transparansi, akuntabilitas, responsibilitas, independensi serta kewajaran dan kesetaraan. Menurut Indra surya (2006:25) good corporate governance dibangun melalui kultur organisasi, nilai - nilai, sistem, berbagai proses, kebijakan - kebijakan dan struktur organisasi yang bertujuan untuk mencapai bisnis yang menguntungkan, efesien dan efektif dalam mengelola risiko dan bertanggung jawab dengan memperhatikan kepentingan stakeholder. Good corporate governance merupakan sebuah metode dan sistem yang digunakan oleh pemegang saham, komisaris, dan direksi dalam rangka meningkatkan kesuksesan bisnis dan akuntabilitas perusahaan agar tetap memperhatikan kepentingan stakeholder sesuai dengan peraturan undang undang dan nilai - nilai etika (Sutedi, 2010). Manfaat bagi perusahaan yang menerapkan good corporate governance secara ekonomis akan menjaga kelangsungan usaha. Selain itu dapat menghilangkan kolusi,korupsi dan nepotisme, dan Meningkatkan kepercayaan baik investor maupun kreditor (Daniri, 2015). Good corporate governancemenekankan pentingnya hak pemegang saham untuk memperoleh informasi dengan benar dan tepat waktu. Mekanisme good corporate governance yang baik akan memberikan perlindungan kepada para pemegang saham dan direktur untuk memperoleh kembali atas investasi dengan wajar, tepat dan seefisien mungkin serta memastikan bahwa manajemen bertindak sebaik yang dapat dilakukannya untuk kepentingan perusahaan (Sukandar, 2014).

Good corporate governance merupakan salah satu hal yang sangat penting dalam tata kelola perusahaan, mengingat sering terjadi kesalahpahaman dan perselisihan kepentingan antara manajemen dan pemilik perusahaan dalam mengambil keputusan. Pemisahan ini didasarkan pada Agency Theory yang dalam hal ini manajemen cenderung akan meningkatkan keuntungan Pribadinya dari pada tujuan Perusahaan. Besarnya proporsi saham yang dimiliki oleh manajerial akan berdampak pada pengambilan keputusan dan kinerja perusahaan. Tingginya kepemilikan saham oleh pihak manajerial akan memperkecil kecenderungan manajer untuk melakukan tindakan konsumsi demi kepentingan individu (Prahesti, 2013). Menurut Agency Theoryprincipal selaku pemegang saham atau Owner mempekerjakan agent atau menejer untuk mengelolah resource yang dimiliki secara efesien dan efektif untuk memberikan profit dan sustainability perusahaan (Jensen dan Meckling, 1976).

Permasalahan goodcorporate governance mengemukan sejak terjadi krisis ekonomi yangmelanda negara-negara Asia termasuk Indonesia, dan semakin menjadi perhatianakibat banyak terungkapnya kasus-kasus manipulasi laporan keuangan. Boediono (dalam Hardikasari, 2011), menyebutkan beberapa kasus yang terjadi di Indonesia, seperti kasus Bank Century juga melibatkan pelaporan keuangan (financial reporting) yang berawal dari terdeteksinya indikasi manipulasi penyelewengan dana dengan modus menjual reksa dana fiktif kepada para nasabah. Rendahnya pengawasan dari pihak perusahaan, hubungan investor yang lemah, kurangnya tingkat transparansi, ketidak efisienan dalam laporan keuangan, dan masih kurangnya penegakan hukum atas perundang-undangan dalam menghukum pelaku dan melindungi pemegang saham minoritas, menjadi pemicu dan alasan beberapa perusahaan perbankan di Indonesia 
mengalami vailid (Hardikasari, 2011). Mekanisme yang dapat dilakukan untuk mengatasi masalah ini adalah dengan menerapkan tata kelola perusahaan yang baik good corporategovernance.

Good corporate governance merupakan bentuk pengelolaan perusahaan yang baik, dimana didalamnya tercakup suatu bentuk perlindungan terhadap kepentingan pemegang saham (publik) sebagai pemilik perusahaan dan kreditor sebagai penyandang (publik) sebagai pemilik perusahaan dan kreditor sebagai penyandang. Berdasarkan latar belakang masalah yang telah diuraikan di atas, maka permasalahan yang diteliti yang pertama adalah untuk mengetahui pengaruh jumlah dewan komisaris independen terhadap kinerja perusahaan, yang kedua untuk mengetahui pengaruh jumlah dewan direksi terhadap kinerja perusahaan, lalu yang ketiga untuk mengetahui pengaruh jumlah komite audit terhadap kinerja perusahaan dan yang terakhir untuk mengetahui dewan komisaris independen, dewan direksi, komite audit berpengaruh secara simultan terhadap kinerja perusahaan.Berdasarkan latar belakang masalah diatas, menarik untuk diteliti sejauh mana tingkat keberhasilan perusahaan dalam menerapkan good corporate governance serta pengaruhnya terhadap kinerja perusahaan.

\section{KAJIAN PUSTAKA}

\section{Kinerja Perusahaan}

Kinerja Perusahaan adalah suatu tampilan keadaan secara utuh atas perusahaan selama periode waktu tertentu, atau sebagai kemampuan perusahaan untuk meraih tujuannya melalui pemakaian sumber daya secara efisien dan efektif dan menggambarkan seberapa jauh suatu perusahaan mencapai hasilnya setelah dibandingkan dengan kinerja terdahulu (Mulyadi : 328 dalam Nugrahayu dan Retnani 2015. Kinerja perusahaan adalah kemampuan sebuah perusahaan mengelolah sumber daya yang ada sehingga dapat memberikan nilai kepada perusahaan tersebut, selain itu kinerja perusahaan bermanfaat untuk mengetahui sejauh mana perkembangan suatu perusahaan. Penilaian kinerja perusahaan adalah penentuan secara periodek efektivitas operasional organisasi, bagian organisasi, dan karyawannya berdasarkan sasaran, standar, dan kriteria yang telah ditetapkan sebelumnya.

\section{Good Corporate Governance}

Good corporate governance (GCG) adalah suatu sistem yang mengatur mengelola dan mengawasi proses pengendalian usaha yang berjalan secara berkesinambungan (sustainable) untuk menaikan nilai saham, sebagai bentuk pertanggungjawabankepada shareholders dan meningkatkan kepatuhan terhadap peraturan perundang - undangan serta nilai - nilai etika yang berlaku secara umum. Pasal 1 Surat Keputusan Menteri BUMN No.117/M-MBU/2002 tanggal 31 Juli 2002 tentang Penerapan GCG pada BUMN menyatakan bahwa GCG adalah suatu proses dan struktur yang digunakan oleh organ BUMN untuk meningkatkan keberhasilan usaha dan akuntabilitas perusahaan guna mewujudkan nilai pemegang saham dalam jangka panjang dengan tetap memperhatikan pemangku kepentingan (stakeholder) lainnya, berlandaskan peraturan perundang-undangan dan nilai-nilai etika.

\section{Dewan Komisaris Independen}

Dewan Komisaris Independen adalah angota dewan komisaris yang tidak 
terafiliasi dengan direksi, anggota dewan komisaris lainnya dan pemegang saham pengendali, serta bebas dari hubungan bisnis atau hubungan lainnya yang dapat mempengaruhi kemampuannya untuk bertindak independen atau bertindak semata-mata demi kepentingan perusahaan (Komite Nasional Kebijakan corporate governance, 2004).

\section{Dewan Direksi}

Dewan Direksi adalah sekelompok individu yang dipilih oleh pemegang saham perusahaan untuk mewakili kepentingan perusahaan dan memastikan bahwa manajemen perusahaan bertindak atas nama mereka. Mereka biasanya bertemu secara berkala untuk menetapkan kebijakan bagi manajemen dan juga untuk pengawasan perusahaan.

\section{Komite Audit}

Komite Audit Menurut (Syafiqurrahman, dkk. 2014) komite audit dibentuk oleh dewan komisaris yang fungsinya bertanggungjawab untuk membantu auditor agar terjaganya independensi manajemen. Tugas dari komite audit adalah membantu dewan komisaris untuk memantau dan memastikan sistem pengendalian internal dan pelaksanaan tugas auditor terlaksana,untuk melakukan penelaahan atas informasi keuanagn yang akan dikeluarkan emiten atau perusahaan publik kepada publik

\section{Teory Agency}

Teori Agensi menjelaskan perilaku suatu perusahaan dari perspektif berbagai kontrak antara berbagai pihak. Pemegang saham yang menyumbangkan dana bagi perusahaan untuk beroperasi tidak dianggap sebagai pemilik perusahaan, mereka adalah pengambil risiko perusahaan.Dalam teori keagenan menjelaskan tentang dua pelaku ekonomi yang saling bertentangan yaitu prinsipal dan agen. Hubungan keagenan merupakan suatu kontrak dimana satu atau lebih orang (prinsipal) memerintah orang lain (agen) untuk melakukan suatu jasa atas nama prinsipal serta memberi wewenang kepada agen membuat keputusan yang terbaik bagi prinsipal (Ichsan, 2013).

\section{Return On Assets (ROA)}

Return On Assets adalah salah satu jenis rasio profitabilitas yang mampu menilai kemampuan perusahaan dalam hal memperoleh laba dari aktiva yang digunakan. Ada pun keunggulan alat ukur kinerja perusahaan Return on assets (ROA) menurut beberapa para ahli :

Menurut Munawir (2001: 91-92) keunggulan Return on assets (ROA) yaitu :

1. Dapat diperbandingkan dengan rasio industri sehingga dapat diketahui posisi perusahaan terhadap industri. Hal ini merupakan salah satu langkah dalam perencanaan strategi.

2. Jika perusahaan telah menjalankan praktik akuntansi dengan baik maka dengan analisis Return on asset (ROA) dapat diukur efisiensi penggunaan modal yang menyeluruh, yang sensitif terhadap setiap hal yang mempengaruhi keadaan keuangan perusahaan.

Menurut Abdul Halim dan Supomo (2001: 151) keunggulan Return on asset (ROA) adalah sebagai berikut :

1. Perhatian manajemen dititik beratkan pada maksimalisasi laba atas modal yang diinvestasikan.

2. ROA dapat dipergunakan untuk mengukur efisiensi tindakan-tindakan yang dilakukan oleh setiap divisinya dan pemanfaatan akuntansi divisinya. Selanjutnya 
dengan ROA akan menyajikan perbandingan berbagai macam prestasi antar divisi secara obyektif.

Analisa ROA dapat juga digunakan untuk mengukur profitabilitas dari masing-masing produksi yang dihasilkan oleh perusahaan.

\section{METODA PENELITIAN}

\section{Gambaran Singkat Objek Penelitian}

Penelitian dilakukan di Perusahaan Perbankan Yang Terdaftar di Bursa Efek Indonesia (BEI) melalui website resmi yang dimiliki oleh BEI yaitu www.idx.co.id. Periode Laporan Keuangan yang diambil tahun 2017 - 2020.

\section{Populasi Dan Sampel Penelitian \\ Populasi}

Populasi penelitian menurut Sugiyono (2017:2) adalah wilayah generalisasi yang terdiri atas: objek/subjek yang mempunyai kuantitas dan karakteristik tertentu yang diterapkan oleh peneliti untuk mempelajari dan kemudian ditarik kesimpulannya.Populasi yang penulis gunakan dalam penelitian ini adalah 46 perusahaan perbankan yang terdaftar di BEI periode $2017-2020$.

\section{Sampel}

Sampel penelitian adalah bagian dari jumlah dan karakteristik yang dimiliki oleh populasi.Metode pemilihan sampel dalam penelitian ini adalah menggunakan metode purposive sampling,pengambilan sampel dengan menggunakan metode purposive sampling karena dalam pengambilan sampling mempunyai tujuan yakni mengambil sampel dengan kriteria-kriteria berikut:

1. Tersedia lengkap laporan keuangan dan laporan tahunan perusahaan perbankan periode 2017-2020.

2. Perusahaan Jenis Perbankan yang telah Listed di Bursa Efek Indonesia tahun 2017 2020

3. Perusahaan Perbankan yang menerapkan good corporate governance di Bursa Efek Indonesia tahun2017 - 2020.

Tabel 1 Pemilihan Sampel

\begin{tabular}{|l|l|}
\hline \multicolumn{1}{|c|}{ Keterangan } & Jumlah \\
\hline $\begin{array}{l}\text { Perusahaan Perbankan yang terdaftar di Bursa Efek Indonesia (BEI) tahun 2017-2020. } \\
\text { Purposive Sampling dengan Kriteria: } \\
\text { 1. } \quad \begin{array}{l}\text { Perusahaan yang tidak menyediakan lengkap laporan keuangan dan laporan tahunan } \\
\text { perusahaan periode 2017-2020. }\end{array}\end{array}$ & 46 \\
$\begin{array}{l}\text { Perusahaan Jenis Perbankan yang tidak Listed di Bursa Efek Indonesia tahun } 2017- \\
\text { 2020 }\end{array}$ & (10) \\
Perusahaan yang tidak menerapkan good corporate governancetahun 2017-2020. & (26) \\
\hline Jumlah perusahaan yang menjadi sampel penelitian & 10 \\
\hline
\end{tabular}

Berdasarkan kriteria yang telah ditetapkan, maka terdapat 10 perusahaan yang 
akan menjadi sampel dalam penelitian ini, Adapun daftar perusahaan dalam penelitian ini adalah sebagai berikut:

\section{Tabel 2 Daftar Perusahaan Sampel}

\begin{tabular}{|c|l|l|}
\hline No. & \multicolumn{1}{|c|}{$\begin{array}{c}\text { Kode } \\
\text { Perusahaan }\end{array}$} & \multicolumn{1}{c|}{ Nama Perusahaan } \\
\hline 1. & BBCA & PT Bank Central Asia Tbk \\
\hline 2. & BBKP & PT Bank KB Bukopin Tbk \\
\hline 3. & BACA & PT Bank Capital Indonesia Tbk \\
\hline 4. & BMAS & PT Bank Bumi Arta Tbk \\
\hline 5. & BMRI & PT Bank Mandiri Tbk \\
\hline 6. & BBNI & PT Bank Negara Indonesia Tbk \\
\hline 7. & BBRI & PT Bank Rakyat Indonesia Agroniaga Tbk \\
\hline 8. & BBMD & PT Bank Danamon Indonesia Tbk \\
\hline 9. & BNII & PT Bank Maybank Indonesia Tbk \\
\hline 10. & BNLI & Bank Permata Tbk \\
\hline & &
\end{tabular}

Sumber data diolah.

\section{Jenis Penelitian}

Jenis penelitian ini menggunakan data sekunder yang bersifat kuantitatif dari laporan keungan perusahaan perbankan yang terdaftar di Bursa Efek Indonesia, yang disajikan kepada publik secara lengkap periode 2017-2020.

\section{Identifikasi Variabel Penelitian}

\section{Variabel Bebas ( Independent Variabel)}

$\mathrm{X} 1=$ Jumlah Dewan Komisaris Independen

$\mathrm{X} 2=$ Jumlah Dewan Direksi

X3= Jumlah Komite Audit

Variabel Terikat (Dependent Variabel)

$\mathrm{Y}=$ Kinerja perusahaan

\section{Definisi Operasional Variabel}

\section{Variabel Bebas}

Menurut Sugiyono (2017:39) variabel bebas adalah variabel yang mempengaruhi atau menjadi sebab perubahannya atau timbulnya variabel terikat. Dalam penelitian ini variabel bebas adalah sebagai berikut:

1. Dewan komisaris independen pihak yang berfungsi mengawasi laporan yang akurat, yang sangat berpengaruh pada tingkat ukuran manajemen laba yang dilakukan pihak perusahaan.

2. Dewan direksi bertanggung jawab penuh atas semua bentuk kegiatan operasional dan kepengurusan perusahaan untuk melaksanakan kepentingan untuk pencapaian tujuan perusahaan. 
3. Komite audit merupakan sebuah komite yang ditunjuk oleh perusahaan sebagai penghubung antara dewan direksi dan audit eksternal, internal auditor serta anggota independen.

\section{Variabel Terikat}

Menurut Sugiyono (2017:80) mengemukakan bahwa variabel terikat sering disebut variabel output, kriteria, konsekuen. Variabel terikat merupakan variabel yang dipengaruhi atau yang menjadi akibat karena adanya variabel bebas. Dalam penelitian ini yang merupakan variabel terikat adalah kinerja. Kinerja perusahaan merupakan suatu gambaran tentang kondisi keuangan suatu perusahaan yang dianalisis dengan alat - alat analisis keuangan, sehingga dapat diketahui mengenai baik buruknya keadaan keuangan suatu perusahaan yang mencerminkan prestasi kerja dalam periode tertentu.

\section{Metode Analisis Data \\ Uji Asumsi Klasik \\ Uji Normalitas}

Uji normalitas bertujuan untuk menguji apakah dalam model regresi variabel pengganggu atau residual memiliki distribusi normal. Dalam penelitian ini, peneliti menggunakan uji Kolmogrov-Smirnov untuk menentukan apakah data terdistribusi normal atau tidak. Jika nilai signifikansinya $\geq 0,05$ maka asumsi normalitas dapat terpenuhi, namun apabila lebih kecil dari 0,05 maka data tersebut tidak berdistribusi normal (Ghozali, 2013:160).

\section{Uji Multikolinieritas}

Menurut Ghozali (2013:105), uji multikolonieritas bertujuan untuk menguji apakah model regresi ditemukan adanya korelasi antar variabel bebas (independen). Model regresi yang baik seharusnya tidak terjadi korelasi antar variabel independen. Untuk mendeteksi ada tidaknya multikolinieritas dapat dilihat dari nilai tolerance value dan variance inflation factor (VIF).

\section{Uji Autokorelasi}

Uji autokorelasi bertujuan untuk menguji apakah dalam model regresi linier ada korelasi antara kesalahan pengganggu pada periode dengan kesalahan pengganggu pada periodet-1(sebelumnya). Jika terjadi korelasi, maka dinamakan ada problem auto korelasi. Auto korelasi muncul karena observasi keobservasi lainnya. Hal ini sering ditemukan pada data runtut waktu (timeserries) karena "gangguan" pada seseorang individu / kelompok cenderung mempengaruhi "gangguan" pada individu / kelompok yang sama pada periode berikutnya (Ghozali, 2013:160).

\section{Uji Heteroskedastisitas}

Menurut Ghozali (2013:139), uji heteroskedastisitas bertujuan menguji apakah dalam model regresi terjadi ketidaksamaan variance dari residual satu pengamatan kepengamatan yang lain. Jika variance dari residual satu pengamatan ke pengamatan lain tetap, maka disebut homoskedastisitas dan jika berbeda disebut heteroskedastisitas. Model regresi yang baik adalah yang homoskedastisitas. Salah satu cara untuk mendeteksi terjadinya heteroskedastisitas atau tidak adalah dengan melihat grafik plot 
antara nilai prediksi variable dependen yaitu ZPRED dengan residualnya SRESID, deteksiada tidaknya heteroskedastisitas dapat dilakukan dengan melihat ada tidaknya pola tertentu pada grafik scatterplot antara SRESID dan ZPREAD. Dasar analisis yang digunakan adalah:

(1)jika ada pola tertentu, sepertititik-titik yang ada membentuk pola tertentu yang teratur (bergelombang, melebar kemudian menyempit), maka mengidikasikan telah terjadi heteroskedastisitas

(2) jika tidak ada pola yang jelas,serta titik-titik menyebar diatas dan dibawah angka 0 pada sumbu Y, maka tidak terjadi heteroskedastisitas.

\section{Analisis Regresi Berganda}

Analisis data dalam penelitian ini dilakukan dengan analisis regresi berganda untuk pengujian hipotesis. Analisis regresi berganda adalah hubungan secara linear antara dua atau lebih variabel independen $(\mathrm{X} 1, \mathrm{X} 2,,,,, \mathrm{Xn})$ dengan variabel dependen Y. Analisis ini untuk mengetahui arah hubungan antara variabel independen dengan variabel dependen apakah masing - masing variabel independen berhubungan positif atau negatif dan untuk memprediksi nilai dari variabel dependen apabila nilai variabel independen mengalami kenaikan atau penurunan. Penelitian ini untuk menguji pengaruh dari jumlah dewan komisaris independen (X1), jumlah dewan direksi (X2), jumlah komite audit X3 yang merupakan variabel independen.Dalam penelitian ini dengan variabel dependennya yaitu Kinerja Perusahaan yang diukur menggunakan ROA. Berdasarkan variabel independen dan dependen tersebut maka dapat disusun persamaan sebagai berikut :

Penelitian ini menggunakan variabel kontrol sebagai perbandingan, maka dapat disusun persamaan sebagai berikut:

Model regresi :

$$
\mathrm{Y} 1=\mathrm{a}+\mathrm{b} 1 \mathrm{X} 1+\mathrm{b} 2 \mathrm{X} 2+\mathrm{b} 3 \mathrm{X} 3+\mathrm{e}
$$

Keterangan :

$$
\begin{array}{ll}
\mathrm{Y} 1 & =\text { Kinerja Perusahaan }(\mathrm{ROA}) \\
\mathrm{a} & =\text { Konstanta } \\
\mathrm{b} 1,2,3 & =\text { Koefisien regresi } \\
\mathrm{X} 1 & =\text { Dewan Komisaris Independen } \\
\mathrm{X} 2 & =\text { Dewan Direksi } \\
\mathrm{X} 3 & =\text { Komite Audit } \\
\mathrm{e} & =\text { standard error }
\end{array}
$$

\section{Uji Hipotesis}

Nilai KoefisienDeterminasi $\left(\mathbf{R}^{2}\right)$

Nilai Koefisien Determinasi $\left(\mathrm{R}^{2}\right)$ digunakan untuk mengukur seberapa jauh kemampuan variabel-variabel independen. Nilai $R^{2}$ adalah antara 0 dan 1 . Nilai $R^{2}$ yang kecil berarti kemampuan variabel-variabel independen menjelaskan variabel dependen amat terbatas. Jika $\mathrm{R}^{2}$ sama dengan 0 , maka variabel independen tidak berpengaruh terhadap variabel dependen dan jika $\mathrm{R}^{2}$ mendekati angka 1,maka variabel independen berpengaruh sempurna terhadap variabel dependen.

\section{Uji Signifikan Parsial (Uji t)}

Uji t digunakan untuk menguji pengaruh dari seluruh variabel independent secara parsial terhadap variabel dependent. Pada uji t, nilai t hitung akan dibandingkan dengan nilai t tabel, apabila t hitung > t table maka Ho ditolak dan H1 diterima. Demikian pula sebaliknya. Adapun hipotesis dirumuskan sebagai berikut : 


$$
H_{1}: b_{1} \neq 0
$$

Artinya terdapat pengaruh yang significant dari variabel independent $\left(\mathrm{X}_{\mathrm{i}}\right)$ terhadap variabel dependent (Y).

Sedangkan nilai t-hitung diperoleh dari perumusan :

Keterangan :

$$
\text { t-hitung }=\frac{B_{i}}{S_{e}\left(B_{i}\right)}
$$

$\mathrm{B}_{\mathrm{i}}:$ Koefisien regresi

$\mathrm{S}_{\mathrm{e}}\left(\mathrm{B}_{\mathrm{i}}\right)$ : Standar eror

\section{Uji Signifikan Simultan (Uji F)}

Uji F digunakan untuk menguji pengaruh dari seluruh variabel independent secara bersama-sama terhadap variabel dependent. Hipotesis ini dirumuskan sebagai berikut :

$$
\mathrm{H}_{1}: \mathrm{b}_{1}, \mathrm{~b}_{2}, \mathrm{~b}_{3} \neq 0
$$

Artinya terdapat pengaruh yang significant secara bersama - sama dari variabel independent $\left(\mathrm{X}_{1}, \mathrm{X}_{2}\right.$ dan $\left.\mathrm{X}_{3}\right)$ terhadap variabel dependent $(\mathrm{Y})$. Apabila $\mathrm{F}$ hitung $>\mathrm{F}$ tabel maka Ho ditolak dan H1 diterima. Demikian pula sebaliknya. Sedangkan nilai Fhitung diperoleh dari perumusan :

Keterangan :

$$
F \text {-hitung }=\frac{R^{2} /(K-1)}{\left(1-R^{2}\right) /(n-K)}
$$

R2: Koefisien determinasi

$\mathrm{K}$ : Jumlah variabel

$\mathrm{n}$ : Jumlah pengamatan

\section{ANALISIS DAN PEMBAHASAN}

\section{Pengaruh Jumlah Dewan Komisaris Independen terhadap Kinerja Perusahaan}

Berdasarkan hasil penelitian membuktikan bahwa variabel jumlah dewan komisaris independen berpengaruh negatif signifikan terhadap kinerja perusahaan. Dengan demikian hipotesis yang menyatakan kinerja perusahaan berpengaruh negatif signifikan terhadap kinerja perusahaan diterima.Demikian Hasil penelitian ini menyatakan semakin banyak jumlah dewan komisaris independen maka kinerja Perusahaan menurun, karena keberadaan dewan komisaris independen mengarah pada keterbukaan dan transparansi laporan keuangan, menjamin akuntabilitas perusahaan oleh karena itu biasanya jumlah dewan komisaris independen pada sebuah perusahaan dibatasin agar tidak mengurangi kinerja sebuah perusahaan.Penelitian ini tidak sesuai dengan penelitian yang dilakukan oleh Ike Citra Merryana dkk (2019) serta penelitian Inka Novitasari dkk (2020) yang menyatakan jumlah dewan komisaris independen tidak berpengaruh terhadap kinerja perusahaan.

\section{Pengaruh Jumlah Dewan Direksi terhadap Kinerja Perusahaan}

Berdasarkan hasil perhitungan membuktikan bahwa variabel jumlah dewan direksi berpengaruh positif signifikan terhadap kinerja perusahaan. Dengan demikian hipotesis yang menyatakan jumlah dewan direksi berpengaruh positif terhadap kinerja perusahaan diterima.Penelitian ini bertolak belakang dengan penelitian yang dilakukan 
oleh Evelyn Setaiwan dkk,(2017) yang menyatakan jumlah dewan direksi tidak berpengaruh terhadap kinerja perusahaan, Namun didukung oleh penelitian Melia Agustina Tetius dkk, (2015) dan Dian pahlawan dkk, (2018) yang menyatakan jumlah dewan direksi berpengaruh positif terhadap kinerja perusahaan. Dewan direksi mempunyai peran yang sangat penting mengupayakan tercapainya target perusahaan, menetapkan sasaran kinerja sehingga sangat sangat berpengaruh terhadap kinerja Perusahaan. Demikian hasil penelitian menunjukkan bahwa dengan menambah jumlah dewan direksi maka akan semakin meningkatkan kinerja perusahaan.

\section{Pengaruh Jumlah Komite Audit Terhadap Kinerja Perusahaan}

Berdasarkan hasil penelitian yang dilakukan menunjukkan variabel jumlah komite audit tidak berpengaruh signifikan terhadap kinerja perusahaan. Dengan demikian hipotesis yang menyatakan jumlah komite auditberpengaruh terhadap kinerja perusahaan ditolak. hal ini berarti komite audit belum dapat memaksimalkan dalam membantu dewan komisaris atau dewan pengawas untuk menjalankan fungsi pengawasan terhadap kinerja keuangan. Dimana jumlah anggota komite audit belum dapat mengontrol manajemen bekerja untuk kepentingan dan tujuan perusahaan agar kinerja keuangan menjadi baik. Hasil penelitian ini didukung Novi Daru Pratiwi dkk (2017), Inka Novitasari dkk (2020), dan Devilia dkk (2021), yang menyatakan jumlah komite audit tidak berpengaruh terhadap kinerja.

\section{Pengaruh Jumlah Dewan Komisaris Independen, Jumlah Dewan Direksi, Jumlah Komite Audit Berpengaruh Secara Simultan Terhadap Kinerja Perusahaan}

Berdasarkan hasil penelitian yang dilakukan pada uji $\mathrm{F}$ secara simultan bahwa variabel jumlah dewan komisaris independen, jumlah dewan direksi, jumlah komite audit berpengaruh signifikan dan positif terhadap kinerja perusahaan. Jumlah dewan komisaris , jumlah dewan direksi, jumlah komite audit, bagian dari indikator good corporate governance secara bersama sama mempengaruhi kinerja perusahaan. Sehingga perusahaan harus tetap menerapakan tata kelola perusahaan yang baik sehingga kinerja perusahaan tetap terjaga dan mendapatkan hasil yang maksimal.

\section{KESIMPULAN}

Penelitian ini menguji tentang pengaruh penerapan good corporate governance terhadap kinerja perusahaan dengan menggunakan analisis regresi linear berganda,berdasarkan hasil penelitian, maka simpulan yang dapat diperoleh sebagai berikut:

Jumlah dewan komisaris independen secara parsial berpengaruh negatif terhadap kinerja perusahaan, jumlah dewan direksi berpengaruh positif terhadap kinerja perusahaan perbankan yang ada di Bursa Efek Indonesia. Jumlah komite audit tidak berpengaruh terhadap Kinerja Perusahaan Perbankan yang ada di Bursa Efek Indonesia Namun Secara bersama-sama (simultan) variabel Dewan Komisaris Independen, Dewan Direksi dan Komite Audit berpengaruh signifikan terhadapKinerja perusahaan yang ada di Bursa Efek Indonesia.

Hasil penelitian ini menunjukkan bahwa sebaiknya perusahaan membatasi jumlah dewan komisaris independen dikarenakan semakin banyak jumlah dewan komisaris independen malah menghambat kinerja perusahaan. Namun Jumlah dewan direksi lebih diperhatikan 
lagi karena dewan direksi mempunyai peran yang sangat penting dalam meningkatkan kualitas strategi dan pengawasan, serta bertanggung jawab penuh atas kerugian yang terjadi dalam perusahaan sehingga berpengaruh terhadap kinerja Perusahaan.Komite Audit sebagai pemantau saat berjalannya Audit perusahaan sehingga biasanya dalam sebuah perusahaan jumlah anggota komite audit juga dibatasi.

\section{SARAN}

Berdasarkan hasil analisis pembahasan dan kesimpulan pada penelitian ini, saran yang dapat diberikan untuk peneliti selanjutnya sebagai berikut:

a. Menambah variabel-variabel lain yang dapat mempengaruhi kinerja perusahaan.

Misalnya: kualitas audit, ukuran perusahaan dan sebagainya.

b. Sebaiknya menambah periode penelitian agar penelitian dilakukan lebih akurat

c. Melakukan penelitian yang serupa disektor yang berbeda.

\section{DAFTAR PUSTAKA}

Devilia, Andrian Budi Prasetyo (2021). Pengaruh Good Corporate Governance Terhadap Kinerja Perusahaan (Studi Empiris pada perusahaan Sektor Properti yang terdaftar di Bursa Efek Indonesia Tahun 2017 - 2019)”.

Devilia, Andrian Budi Prasetyo (2021). Pengaruh Good Corporate Governance Terhadap Kinerja Perusahaan (Studi Empiris pada perusahaan Sektor Properti yang terdaftar di Bursa Efek Indonesia Tahun 2017 - 2019)”.

Dewi Wulandari. (2020). Pengaruh Mekanisme Good Corporate Governance Terhadap Kinerja Perusahaan (Studi Empiris pada perusahaan Sektor Properti yang terdaftar di Bursa Efek Indonesia Tahun 2016 - 2018)”.

Dian Pahlawan, Hari Purnomo, Wahyuning Murniati (2085). Analisis Pengaruh Good Corporate Governance Terhadap Kinerja Perusahaan (Studi Pada Perusahaan Manufaktur Yang terdaftar di BEI periode 2014 - 2016).

Effrita Ayuningtyas, Kartika Hendra Titisari, Siti Nurlaela (2020). Pengaruh Good Corporate Governance Terhadap Kinerja Perusahaan Pada Bank Go Public di BEI Tahun 2014 - 2018.

Evelyn Setiawan,Yulius Jogi Christiawan (2017). Pengaruh Good Corporate Governance Terhadap Nilai Perusahaan dengan Ukuran Perusahaan dan Leverage Sebagai Variabel Kontrol.

Ike citra Merryana Anggita Langgeng Wijaya,M. Agus Sudrajat (2019). Pengaruh Good Corporate Governance Terhadap Kinerja Perusahaan Perbankan Indonesia. 
Inka Novitasari, I Dewa Made Endiana,Putu Edy Arizona (2020). Pengaruh Mekanisme Good Corporate Governance Terhadap Kinerja Perusahaan Yang terdaftar di BEI.

Melia Agustina Tertius dan Yulius Jogi Christiawan,Se.,M.Si,Ak (2015)Pengaruh Good Corporate Governance Terhadap Kinerja Perusahaan Pada Sektor Keuangan.

Novi Daru Pratiwi.Azfa Mutiara Ahmad Pabulo,Fajar Aribowo (2017). Analisis Pengaruh Good Corporate Governance Terhadap Kinerja Perusahaan Pada Perusahaan Manufaktur.

Tutut Istiana,Leonardo Hasiolan,S.E., M.M,Aziz Fathoni,S.E., M.M(2014). Analisis Pengaruh Good Corporate Governance Terhadap kinerja Perusahaan 